\title{
A relação ensino-aprendizado e suas consequências na produção do conhecimento científico
}

\author{
The teaching-learning relationship and its consequences on the \\ production of scientific knowledge.
}

Anselmo Gomes de Oliveira;

Dâmaris Silveira

Editores-Chefe

Muito tem sido divulgado, atualmente, que a relação crise-ciência é uma questão financeira. Entretanto, quando o problema é analisado mais profundamente fica mais visível que a questão contábil existe, mas outros fatores importantes parecem também ter efeito tão significante quanto o financeiro. Enquanto o ensino e a ciência não forem uma das prioridades em nosso país não há chances de progressão. Evidentemente a crise não é exclusividade desses setores, mas está institucionalizada no Brasil, de forma que enquanto esses problemas perdurarem haverá quase nenhuma chance de progredirmos nessas áreas. Por enquanto resta-nos abrir caminhos que permitam a valorização da divulgação científica, como forma de valorizar a ciência que fazemos e, com isso, estar mais próximos da sociedade e das questões sociais.

Por outro lado, embora a formação das pessoas deva começar muito intensamente com o ensino fundamental, no Brasil, a produção em ciência parece ter um estreitamento muito mais ligado com o ensino superior. Na área de Ciências Farmacêuticas, em particular, as últimas diretrizes curriculares foram implantadas por meio da Resolução no 6 de 19 de outubro de 2017 da Câmara de Educação Superior do Conselho Nacional de Educação (1). Evidentemente num país como o Brasil, com grande extensão territorial, regiões distantes e com costumes, vocações regionais e necessidades específicas, existir uma relação ensino-aprendizado tão homogênea que possa ser avaliada utilizando uma única metodologia é extremamente complicado. É certo que as variações regionais imporão parâmetros não contemplados e o resultado disso abrangerá alguns fatores incompreensíveis. Uma análise simplista dos altos índices de rejeição de artigos submetidos para o periódico Infarma-Ciências Farmacêuticas (2), cuja demanda de submissões são de docentes, alunos de pós-graduação e de graduação, além de profissionais, em sua grande maioria da área de Farmácia, expõe certas deficiências na questão da formação. Nos dois últimos anos, a maior proporção de submissões de artigos para o periódico não se enquadra nas áreas técnicas clássicas, mas sim nas novas áreas que se abriram no campo das Ciências Farmacêuticas.

É de se esperar que problemas relacionados a uma formação de excelência ocorram em uma profissão com mais de 100 diferentes possíveis áreas de atuação. Assim, parece ser recomendável um acompanhamento mais aprofundado e constante nessa questão, como meio de se identificar suas principais deficiências na formação farmacêutica. Parece evidente que essas vertentes poderiam estar relacionadas tanto com a formação de recursos humanos direcionados com o ensino de graduação e pós-graduação, quanto simplesmente com o processo de aprendizagem dos estudantes nessas áreas. O importante é ter em mente que, qualquer que seja a área escolhida, sem uma base científica sólida, a excelência profissional fica comprometida.

De qualquer forma, Infarma - Ciências Farmacêuticas, que mantém um rígido sistema de avaliação de textos por pares, tem publicado o que há de melhor nesse campo e com extensa amplitude de assuntos, abrangendo tanto as áreas consolidadas como as emergentes das Ciências Farmacêuticas. Nesse número, os artigos originais e de revisão abordam desde a Farmacobotânica, passando pela Tecnologia Farmacêutica, até a área recentemente incorporada, Estética.

Assim, aos nossos leitores fica o convite para que continuem visitando nosso site em http://revistas.cff. org.br/?journal=infarma. Certamente poderão se surpreender com a diversidade das contribuições de nossos autores. 


\section{REFERÊNCIAS}

1. BRASIL. RESOLUÇÃO No 6, DE 19 DE OUTUBRO DE 2017. Institui as Diretrizes Curriculares Nacionais do Curso de Graduação em Farmácia e dá outras providências. Ministério da Educação, Conselho Nacional De Educação Câmara De Educação Superior. http://portal. mec.gov.br/index.php?option=com_docman\&view $=$ do- wnload\&alias $=74371$-rces006-17-pdf\&category slu$\mathrm{g}=$ outubro-2017-pdf\&Itemid=30192

2. Oliveira AG, Silveira D. Cosntruindo e aprendendo com o trabalho. Infarma - Ciências Farmacêuticas. 2017;29(4):283. DOI: 10.14450/2318-9312.v29. e4.a2017.pp283 